\title{
The Effect Of TGT (Teams Game Tournament) With Snakes And Ladder Media on Primary School Activities and Learning Outcome
}

\author{
Intan Wardhani Putri, Ketut Prasetyo \\ State University of Surabaya \\ Surabaya, Indonesia \\ wardhaniintan22@gmail.com
}

\begin{abstract}
This study aims at determining the influence of team games tournament with snake and ladder media on activities and learning outcomes of fourth-grade elementary school students. This study used a quasi-experiment research design. The research design used was Non-equivalent Control Group Design with observation sheets, test sheets and documentation as the data collection tools. The data analysis method used descriptive analysis and t-test techniques. The finding showed that there were significant differences in the activity and learning outcomes between classes in terms of receiving team games tournament model with snake and ladder media and conventional learning model. The results of this study indicated that the team games tournament with snake and ladder media influenced the activity and learning outcomes of fourthgrade elementary school students.
\end{abstract}

Keywords-Teams games tournament learning model; activity; and learning outcome.

\section{INTRODUCTION}

Education is a process that serves to guide students in interacting in everyday life in accordance with the development that must be carried out by students. Education is a form of business that is conscious, planned and systematically carried out by parties who are given the authority to influence students so as to shape the nature and behavior that is in accordance with the goals of education.

[1] concerning with the National Education System states that "Education is a conscious and planned effort to realize the learning atmosphere and learning process so that students actively develop their potential to have spiritual, religious strength, self-control, personality, intelligence, noble character, and skills needed by himself, society, nation, and state". Thus, education is a form of activity carried out consciously and planned in order to gain knowledge about life, run life processes in society and foster character or attitude.

Knowledge is required to be studied more deeply. Everyone's social knowledge needs to be possessed to help overcome the existing social problems. The provision of social knowledge must also be installed early that the students have a good attitude towards their social environment. With social studies learning in elementary school, the goal of education can be achieved by fostering students' knowledge of experiences in community life, helping students to develop skills to find and manage information, and providing opportunities for students to behave actively into social life. Social studies lessons come from the environment and everyday life. Social studies learning in elementary school does not only provide students with rote concepts but also provides students with the opportunity to participate in community life.

According to [2] "Social Studies is the study of various aspects of the social sciences and humanities disciplines and various activities that are fundamental to providing knowledge and understanding and deep experience to students especially at the elementary and secondary levels." Social studies deal with the study of activities and human social life in various aspects. The minister of National Education Regulation No. 22 of 2006 concerning the Content Standards of social studies subjects have the aim that students are able to carry out daily life as follows: (1) learning a concept related to social life in their environment; (2) ability to think rationally and sensibly, high curiosity, inquiry, find solutions to various problems, and have skills in everyday life; (3) commitment and awareness of social and humanitarian values; (4) ability to connect well, work together and compete in a balanced manner in this diverse society, both at the local, national and global levels.

The results of earlier observations conducted by researchers found several problems. Many students considered Social Studies as a saturating subject, because many students still experienced difficulties in learning social studies. Students still needed a long time to do the assignments from the teacher and still ask other students. The test results were also not satisfactory. Students tended to be lazy to do the work and often cause agitation so that other friends felt disturbed by it. Some students had not applied the concept of Social Studies into their daily lives.

Another important problem was that teachers had not actively involved students, therefore, the learning did not run effectively and did not create saturation, that could make students less motivated in learning social studies. Student activity in social studies learning was still low because the 
teacher did not use learning models in accordance with social studies material. Currently, many teachers had not used a model that could make students interested in learning that students were still confused and had not been directed to understand the concept of the material that had been learned ". Therefore, social sciences or social studies is still considered as a boring lesson. The most important problem in class IV was the low variance of activity and learning outcomes of social studies.

The most prominent problem in the fourth grade of SD Raden Fatah was the low learning outcomes of social studies. Semester 1 test results showed that as many as $75 \%$ or as many as 16 students from 64 students had not budged or received grades below the minimal mastery criteria 75 , and only 48 students $(25 \%)$ scored above the minimal mastery criteria 75 or completed learning. Seeing that percentage, the author the minimal mastery criteria concluded that the cause was the lack of student activity in the classroom in learning. Because the teacher did not use the learning model properly so that students did not understand and master the content of the material that had been taught by the teacher. In order for the objectives in teaching and learning activities to be optimal, teachers were required to master the taught material, be able to classify various types of learning models, have the abilities needed by students, and master the techniques in teaching. The success of students in learning depends on the selection of the right learning model.

Based on the facts, Social Studies need to turn into a fun lesson. To make it a creative, fun, and innovative subject, an appropriate Learning Model is needed to provide a change in the learning. To create interesting learning, one way is to collaborate between students and teachers in Indonesia using a form of learning model that can motivate students to learn [3] It can be in the form of models / methods in learning and media that can support in the learning process. The learning model that can be applied is the Teams Games Tournament (TGT) cooperative learning model.

Learning model is a form of way that is used as a reference in planning learning in class and outside class. "This learning model can be interpreted as a conceptual framework that describes systematic rules in organizing learning experiences to achieve a learning goal." [4] Before choosing a learning model, some considerations must be raised in terms of the purpose, material or subject matter, and students.

The models that fit the subject matter will make students more interested in learning. The selection of the right learning model is oriented to teaching purposes, including the purpose of each material to be covered each meeting given to learners [5] Team Games Tournament (TGT) learning model can provide convenience in learning especially social studies subjects. Team Games Tournament (TGT) learning model is one of the cooperative learning models that is easily applied in learning that involves the activities of all students regardless of race and ethnic differences, involves the role of students as peer tutors, and contains elements of play and reinforcement. Games-based learning has captured the interest of educationists and industrialists who seek to reveal the characteristics of computer games as perceived by some to be a potentially effective approach for teaching and learning [6] This study used a learning model that is modified with snakes and ladders games so that the learning model of teams games tournament with snakes and ladders media would help students to improve their enthusiasm in learning, and it could remind them of the traditional game (snakes and ladders) that children rarely play.

Activities are things that characterize the process of teaching and learning activities in the classroom. Learning is an act and a process that makes students active while teaching is a way for teachers to learn.

Referring to [7], thinking deals with "learning activities are a series of activities that are both physical and mental and the learning activities of both activities are interconnected". "In connection with this, the child is asked to think as long as he acts. Without action means that the child does not think. Therefore, the children need to be encouraged to think for themselves with a verbal level and then carry out those activities with the level of action.

Learning outcomes can be interpreted as the end of learning. If someone has done a learning activity, it will lead to a change in attitude in that person, from not knowing to knowing and from not understanding to understanding. Learning outcomes are the culmination of the learning process.

Model of cooperative learning type this Teams Games tournament is one type of learning that involves 4-5 students per group. Each group is heterogeneous in terms of student ability, gender, and academic achievement in the class group. The students compete against other team members to get a score.

The players include the players who have low abilities to compete with other players with low abilities, and players who have abilities are competing with players with moderate abilities, and players who have high abilities will compete with students who have high abilities as well. Every student has the same opportunity to be successful. Friends help each other to prepare for the tournament, but cannot help each other during the game using snake ladder media in progress. This learning model can be used for all grades and all subjects in school.

Teams games tournament learning model with snake and ladder media in this study was made according to the steps of the team games tournament learning model so that it made the activities of all students in accordance suitable with the level of students' abilities, and create a sense of pleasure towards snake ladder media that would increase the student learning outcomes.

\section{METHODS}

\section{Research design}

This study was a quantitative study with nonequivalent control group design research design. The design of this study 
involved two groups which were then given a pretest to determine the initial state of whether the difference between the experimental group and the control group. The pretest

\begin{tabular}{|c|c|c|c|}
\hline Group & Pretest & Treatment & Posttest \\
\hline $\mathrm{K}_{\mathrm{E}}$ & $\mathrm{O}_{1}$ & $\mathrm{Xe}$ & $\mathrm{O}_{2}$ \\
\hline $\mathrm{K}_{\mathrm{K}}$ & $\mathrm{O}_{3}$ & - & $\mathrm{O}_{4}$ \\
\hline
\end{tabular}

results were good if the value of the experimental group was not significantly different.

The following is the Nonequivalent Control Grub Design chart:

\section{TABLE 1. RESEARCH DESIGN}

$\begin{array}{ll}\text { Exp: } & \\ \mathrm{K}_{\mathrm{E}} & : \text { Experimental Design } \\ \mathrm{K}_{\mathrm{K}} & : \text { Control Group }\end{array}$

O1 and O3: Questionnaire given at the beginning of the lesson $\mathrm{O} 2$ and O4: Questionnaire given at the end of the lesson $\mathrm{X}$ : Manipulation of experimental variables

\section{Participant}

The research subjects were 64 fourth grade students of Raden Fatah Elementary School in Surabaya which consisted of two learning classes. The location of this research was in Raden Fatah Elementary School Surabaya which is located at Jalan Kendung I / 11, Benowo Subdistrict, Surabaya City.

\section{Data collecting technique}

The instruments used in this study were as follows: Observer sheets, test sheets, and documentation. The observer sheet was used to find out the activities of each student. Test sheets were used to measure the success of student learning outcomes, and a documentation sheet was used to find out each student's personal data. This type of instrument was in the form of multiple choice. Observation method is a technique or method of collecting data by making observations of ongoing activities [8] The instruments were first tested on student learning activities and tests of student learning outcomes in elementary science learning. The instrument was made based on the grid. The tested test was then searched for the instrument validity.

A good instrument must fulfill two important requirements, namely validity and reliability which are determined by validity and reliability tests [9] The study was conducted using homemade instruments that had not been standardized, so it was necessary to test the validity of the instrument so that good data was produced.

The instrument was validated to the instrument expert to be asked his opinion about the instrument that had been compiled.
After the instrument had been consulted with experts, the next step was to test the specified sample, then it was analyzed.

The formula used to look for instrument validity was the Product Moment formula.

$$
\mathrm{r}_{\mathrm{xy}}=\frac{N \cdot \Sigma X Y-\Sigma X \cdot \Sigma Y}{\sqrt{\left(\left(N \cdot \Sigma X^{2}\right)(\Sigma X)^{2} l\left(N \cdot \Sigma Y^{2}\right)-\left(\sum Y\right)^{2}\right\}}}
$$

Where:

$\mathrm{r}_{\mathrm{xy}}=$ Correlation coefficient between variable $\mathrm{X}$ and variable $\mathrm{Y}$

$\mathrm{N}=$ Number of students

$\mathrm{X}=$ Score of each item

$\mathrm{Y}=$ total score

The rxy value was then compared with the results of $r$ in the product moment table with a significance level of $5 \%$. Question items were said to be valid if $r$ count $>r$ table. After testing the instrument validity, reliability testing was carried out. Reliable instruments would produce reliable data. If the data was correct in accordance with the reality, then how many times it was taken would remain the same. Reliability refers to the level of reliability of something. Reliable means that it can be trusted to be reliable.

The reliability formula used in this study used the formula of f KR 20 (Kuder Richardson).

$$
\mathrm{r}_{\mathrm{i}}=\frac{k}{(k-1)}\left(\frac{s_{t}^{2}-\sum p i q i}{s_{t}^{2}}\right)
$$

Information:

$\mathrm{k}=$ Number of items in the instrument

$\mathrm{pi}=$ proportion of the number of subjects who answered item 1

$\mathrm{qi}=1-\mathrm{pi}$

$s_{t}^{2}=$ total variance [10]

In a research, data analysis is an activity carried out after all data from respondents collected. These data need to be processed immediately to find out the results of the proposed research variables. The normality test of the sample is done to test the normal or not of the sample. This study examined the normality test hypothesis. The normality test used Liliefors test which states that the statistical hypothesis of the normality test is given as follows:

The use of the Liliefors test is relatively easy and accurate. The procedures for using the Liliefors test are as follows: Standardizing Sample Data. Sample data $X_{1}, X_{2}, X_{3}, \ldots, X_{\mathrm{n}}$ are standardized to become standard numbers $z 1, z 2, z 3, \ldots, z n$ using the formula: $\mathrm{zi}=\frac{x i-\bar{x}}{s}$

Where:

zi: standard number

xi: i value 
$\mathrm{s}$ : standard deviation

$\bar{x}$ : average value

In addition to testing the normal distribution of data in the sample, the researcher required testing of similarity (homogeneity), i.e. similar or unvaried samples taken from the same population. The testing of sample homogeneity become very important if the researcher intends to generalize to the results of his research and research whose research data is taken from separate groups from one population. The homogeneity test in this study was calculated using the F test, with the following formula:

$$
\mathrm{F}=\frac{S_{1}^{2}}{S_{2}^{2}}, \text { where } \mathrm{S}^{2}=\frac{s_{x^{2}}-\frac{\left(s_{x}\right)^{2}}{n}}{n-1}
$$

Where:

$\mathrm{F}=$ Variance sought

$S_{1}^{2}=$ highest variance

$S_{2}^{2}=$ The lowest variance

Decision making and drawing conclusions on the $\mathrm{F}$ test were carried out at a significance level of 0.05 . In the homogeneity test, the expected $\mathrm{F}$ price was the insignificant price of $F$, the price of $F$ is smaller than the $F$ table price contained in the table [11] The decision rule was if $F_{\text {count }}$ $<\mathrm{F}_{\text {table }}$ then the data distribution was homogeneous.

The data obtained from this study were the test data obtained from the pretest and posttest. To see the effect of the learning model of teams games tournament with snake ladder media on student learning outcomes, this study used different test analysis techniques or t-Test. The following t-Test formula used was:

$$
t=\frac{m_{x}-m_{y}}{\sqrt{\frac{\sum^{2}+\sum y^{2}}{N x+N y-2} x \frac{1}{N x}+\frac{1}{N y}}}
$$

Where:

$\mathrm{M}=$ average value of results per group

$\mathrm{N}=$ number of subjects

$\mathrm{x}=$ deviation of the values of $\mathrm{x}_{2}$ and $\mathrm{x}_{1}$

$\mathrm{y}=$ deviation of each $\mathrm{y}_{2}$ value from the mean $\mathrm{y}_{1}$

The $t$ test criteria were carried out by comparing $t$ count with $t$ table. If the $t$ count that appears was negative then there would be a significant difference or influence if $t$ count $<t_{\text {table }}$. If the $t$ count value was positive then there would be a significant effect if the value of $t_{\text {count }}>t$ table meant that there was a significant influence.

\section{RESULT AND DISCUSSION}

From the test of the validity of the instrument, the following results were obtained, namely, the researcher made
40 items tested on the students, there were 5 items that were invalid so that there were 35 valid questions. Then the researcher took 30 items from valid questions for the pretest and posttest questions. The valid question numbers were 1,2,3, $5,6,7,8,9,10,11,13,14,15,16,18,19,20,21,22,23,24$, $25,28,29,30,32,33.37,38,40$.

The reliability of pretest and posttest instruments was carried out on the items that had been calculated for validity through the product moment formula and declared valid. The reliability of pretest and posttest instruments was analyzed through calculations using the KR-20 formula and obtained a certain level of trust. The reliable pretest and posttest instruments could be used to conduct research and could produce reliable data.

Based on the calculation of the reliability, by using the formula K-R 20, it was obtained the value of $\mathrm{r} 11=0.938$ which was then consulted with the correlation table $\left(\mathrm{r}_{\text {table }}\right)$ with $\mathrm{db}=32$ for the $5 \%$ significance level of 0.349 . Thus, the calculated $r$ value was greater than the $r_{\text {table }}$ price $(0.938)>$ 0.349 ). So, it can be concluded that the pretest and posttest instruments used in the study were reliable.

Based on the interpretation of the r11 value listed in table 1 , the instrument of pre-test and post-test had a very high level of reliability because in table 1 , it was stated that if $0.90<\mathrm{r} 11$ $\leq 1.00$ then the reliability level fell into the very category high.

The research was carried out in accordance with the research design namely the initial stage of the experimental class and the control class which was given a pretest to determine the initial ability. Then, the experimental class was given a learning model of teams games tournament with snake ladder media while the conventional learning was given to the control classes. Then, at the end of the learning, the two classes were given a posttest to find out the results of the following day's learning.

From the results of giving the pretest and posttest given to students, the students' scores were obtained. The description of the research data includes (1) description of the data from the pretest results of the experimental class and control class and (2) a description of the experimental class and control class posttest results data. The test given to students was an objective test of 25 questions. The following is a recapitulation of the results of the calculation of the results of the pretest data presented in table 2 . 


\begin{tabular}{|c|c|c|c|c|}
\hline \multirow{2}{*}{ Statistics } & \multicolumn{2}{|c|}{ Experiment Class } & \multicolumn{2}{c|}{ Control Class } \\
\cline { 2 - 5 } & Pretest & Posttest & Pretest & Posttest \\
\hline $\mathrm{N}$ & 32 & 32 & 32 & 32 \\
\hline Mean $(\bar{x})$ & 53,88 & 80,70 & 58,18 & 65,69 \\
\hline $\begin{array}{c}\text { Normal } \\
\text { Deviation }\end{array}$ & 11,57 & 8,554 & 13,53 & 8,833 \\
\hline $\mathrm{L}_{\text {count }}$ & 0,133 & 0,121 & 0,149 & 0,124 \\
\hline $\mathrm{L}_{\text {table }}$ & 0,886 & 0,886 & 0,886 & 0,886 \\
\hline Conclusion & $\begin{array}{c}\text { Normal } \\
\text { distribution }\end{array}$ & $\begin{array}{c}\text { Normal } \\
\text { distribution }\end{array}$ & $\begin{array}{c}\text { Normal } \\
\text { distribution }\end{array}$ & $\begin{array}{c}\text { Normal } \\
\text { distribution }\end{array}$ \\
\hline
\end{tabular}

TABLE 2. RECAPITULATION OF RESULTS OF THE PRETEST VALUE

\begin{tabular}{|c|c|c|}
\hline Data & Experiment Class & Control Class \\
\hline Maximum score & 96 & 84 \\
\hline $\begin{array}{c}\text { Minimum } \\
\text { score }\end{array}$ & 64 & 48 \\
\hline Mean & 80,706 & 65,697 \\
\hline Median & 80 & 68 \\
\hline Modus & 80 & 68 \\
\hline Varians & 73,1836 & 78,0303 \\
\hline Normal Deviation & 8,554 & 8,833 \\
\hline
\end{tabular}

After calculating the pretest, the posttest value was calculated. The following is the recapulation of the posttest results can be seen in table 3 .

\section{TABLE 3. RECAPULATION OF POSTTEST VALUE RESULTS}

Based on the explanation above, to simplify comparisons, the recapitulation data on the average pre-test and post-test values are presented in the following bar diagram:

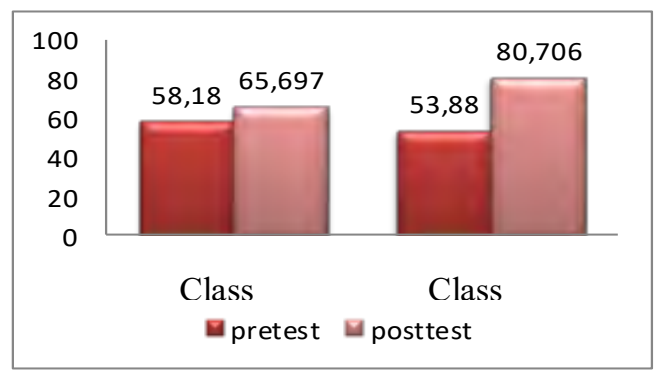

Diagram 1. Comparison of control class and experimental class values, and their completeness

Before testing the hypothesis, the prerequisite analysis test included normality test and homogeneity test. The normality test was performed to find out whether the sample used was a normal distribution or not. In this study, the normality test used is the Liliefors test. The results of the normality test of the experimental class and control class can be seen in table 4.

\section{TABLE 4. RESULTS OF THE NORMALITY TEST CALCULATION}

Test criteria Calculate $\mathrm{L}_{\text {count }}<\mathrm{L}_{\text {table }}$ with a significant level of $5 \%(\mathrm{dk}=$ number of classes minus parameters, minus 1$)$ indicated that the data were normally distributed. Whereas, if $\mathrm{L}_{\text {count }}>\mathrm{L}_{\text {table }}$, the data were not normally distributed.

Based on the analysis of the pretest data of the experimental group by using the liliefors formula, the calculated counting was $\mathrm{L}_{\text {count }} 0.133$ and $\mathrm{L}_{\text {table }} 0.886$. Therefore, the data from the experimental group was $\mathrm{L}_{\text {count }}$ $0.133<\mathrm{L}_{\text {table }} 0.886$, hence, the data was normally distributed. Meanwhile, the pretest data of the control group was obtained by $L_{\text {count }} 0,149$ and $L_{\text {table }} 0,886$. Therefore, the control group result data was $\mathrm{L}_{\text {count }} 0.149<\mathrm{L}_{\text {table }} 0.886$ then the data was normally distributed.

Based on the analysis of the posttest data of the experimental group using the liliefors formula, it was obtained the L count of 0.121 and $\mathrm{L}_{\text {table }} 0.886$. Hence, the data from the experimental group $\mathrm{L}_{\text {count }} 0.121<\mathrm{L}_{\text {table }}$ was 0.886 then the data was normally distributed. Meanwhile, the posttest data of the control group were obtained from $\mathrm{L}_{\text {count }} 0.124$ and 0.886 $\mathrm{L}_{\text {table. }}$ Therefore, the control group result data counts $\mathrm{L}_{\text {count }}$ $0.124<\mathrm{L}_{\text {table }} 0.886$, which meant that the data was normally distributed.

The homogeneity test was carried out on the variance of pairs between the experimental class and the control class. The test used was the F test. The results of the experimental class homogeneity test and control class are shown in table 5 .

TABLE 5. HOMOGENEITY TEST RESULT CALCULATION

\begin{tabular}{|c|c|c|c|c|}
\hline \multirow{2}{*}{ Statistics } & \multicolumn{2}{|c|}{ Pretest } & \multicolumn{2}{c|}{ Posttest } \\
\cline { 2 - 5 } & $\begin{array}{c}\text { Experimen } \\
\text { t Class }\end{array}$ & $\begin{array}{c}\text { Control } \\
\text { Class }\end{array}$ & $\begin{array}{c}\text { Experime } \\
\text { nt Class }\end{array}$ & $\begin{array}{c}\text { Control } \\
\text { Class }\end{array}$ \\
\hline Varians & 134,04 & 183,09 & 73,1836 & 78,0303 \\
\hline $\mathrm{F}_{\text {count }}$ & \multicolumn{2}{|c|}{1,365} & \multicolumn{2}{c|}{1,066} \\
\hline $\mathrm{F}_{\text {table }}$ & \multicolumn{2}{|c|}{1,76} & \multicolumn{2}{c|}{1,76} \\
\hline Conclusion & \multicolumn{2}{|c|}{ Homogen } & \multicolumn{2}{c|}{ Homogen } \\
\hline
\end{tabular}

The criteria for homogeneous data was if $\mathrm{F}_{\text {count }}<\mathrm{F}_{\text {table, }}$, then the data was homogeneous, while $\mathrm{F}_{\text {count }}>\mathrm{F}_{\text {table, then the data }}$ was not homogeneous.

Based on the data above, it can be seen that the value of the pretest of the control class and the experimental class obtained Fcount of 1.365 and Ftable of 1.76, $\mathrm{F}_{\text {count }} 1.365$ $<\mathrm{F}_{\text {table }}$ 1.76. Therefore, the data was homogeneous. Meanwhile, the value of the pretest of the control class and the 
experimental class obtained $F_{\text {count }}$ of 1.066 and $F_{\text {table }}$ of 1.76, $\mathrm{F}_{\text {count }} \mathrm{ed} 1.066<\mathrm{F}_{\text {table }} 1.76$, the data was homogeneous.

Student activity in learning is shown in table 6 below:

TABLE 6. STUDENT ACTIVITIES IN LEARNING

\begin{tabular}{|c|c|c|}
\hline \multirow{2}{*}{ Meeting } & \multicolumn{2}{|c|}{ Percentage } \\
\cline { 2 - 3 } & Control Group & $\begin{array}{c}\text { Experimental } \\
\text { Group }\end{array}$ \\
\hline 1 & $73 \%$ & $78 \%$ \\
\hline 2 & $75 \%$ & $83 \%$ \\
\hline 3 & $74 \%$ & $85 \%$ \\
\hline Percentage & $\mathbf{7 4 \%}$ & $\mathbf{8 2} \%$ \\
\hline
\end{tabular}

Based on Table 6 above, the overall percentage of student activity in the control group was $74 \%$, while the overall percentage of student activity in the control group who used the learning model teams games tournament with snake ladder media reached $82 \%$ belonged into the very high category. From these results, it can be concluded that students who learned using learning models of team games tournament with snake ladder media were more active than students who learned to use conventional learning models.

Based on the results of the prerequisite test for data analysis, testing the research hypothesis was carried out using the $t$ test.

$$
t=\frac{m_{x}-m_{y}}{\sqrt{\frac{\sum x^{2}+\sum y^{2}}{N x+N y-2} \times \frac{1}{N x}+\frac{1}{N y}}}
$$

Where:

$\mathrm{M}=$ average value of results per group

$\mathrm{N}=$ number of subjects

$\mathrm{x}=$ deviation of the values of $\mathrm{x}_{2}$ and $\mathrm{x}_{1}$

$\mathrm{y}=$ deviation of each value of $\mathrm{y}_{2}$ from mean $\mathrm{y}_{1}$

The $t$ test criteria were carried out by comparing $t$ count with $t$ table. If $t$ count appears negative, then there will be a significant difference or influence if $t_{\text {count }}<t_{\text {table. If the tcount }}$ that appears was positive, then there would be a significant effect if the value of $t_{\text {count }}>t_{\text {table. It meant that there was a }}$ significant influence.

From the results of the $t$ test above, the price of $t$ count was compared with the price of $\mathrm{t}$ table with $\mathrm{dk} n 1+\mathrm{n} 2-2=64-2=$ 62 . Based on the $t$ test table, if with 62 tests of two parties with a level of $5 \%$, then the table obtained was 1,670 . So, the value of $\mathrm{t}$ count is 5,378> $\mathrm{t}_{\text {table }}$ of 1,670 , then there would be a significant effect between the experimental class and the control class. Therefore, it could be concluded that Ho was rejected and Ha was accepted, which meant that the learning model of teams games tournament with snake ladder media had a significant influence on learning outcomes. The classes that received learning models of teams games tournament with snake ladder media had a grade average (MY = 26.82) which was higher than the class that used conventional models which obtained a class average $(\mathrm{Mx}=7.51)$.

\section{CONCLUSION}

Based on the results of research conducted at Raden Fatah Elementary School Surabaya, the learning done using models of teams games tournament with snake ladder media affected the activities and learning outcomes of fourth grade elementary school students. The experimental class that used the models of teams games tournament with snake ladder media gained an average of 80.7 learning outcomes. Meanwhile, the control class taught with conventional learning models obtained average value of 65.69 . Based on the formulation of the problem and the purpose of the study with the results of the t-test analysis, it was found that $t_{\text {count }} 5,378$ with $t_{\text {table }}$ at df 62 and the significance level 5\% 1,670 . Therefore, it can be seen that the value of $t_{\text {count }}>t_{\text {table }}(5,378>$ $1,670)$. Hence, the snake ladder social studies had a positive influence towards the activities and learning outcomes of social studies material on economic activities for the students in Raden Fatah Elementary School Surabaya.

\section{References}

[1] P. R. Indonesia, "Undang-undang Republik Indonesia nomor 20 tahun 2003 tentang sistem pendidikan nasional, ” Jakarta Pemerintah Republik Indones., 2003.

[2] M. P. Ahmad Susanto, Teori belajar dan pembelajaran di sekolah dasar. Kencana, 2016.

[3] D. Frianto and A. Amirudin, "The implementation of Cooperative Learning Model Team Game Tournament and Fan N Pick To Enhance Motivation and Social Studies Learning Outcomes," IOSR J. Humanit. Soc. Sci., vol. 21, no. 5, pp. 74-81, 2016.

[4] A. Suprijono, Cooperative learning: teori \& aplikasi PAIKEM. Pustaka Pelajar, 2009.

[5] N. Nadrah, I. Tolla, M. S. Ali, and M. Muris, "The Effect of Cooperative Learning Model of Teams Games Tournament (TGT) and Students' Motivation toward Physics Learning Outcome," Int. Educ. Stud., vol. 10, no. 2 , p. 123, 2017.

[6] A. Salam, A. Hossain, and S. Rahman, "Effects of Using Teams Games Tournaments (TGT) Cooperative Technique for Learning Mathematics in Secondary Schools of Bangladesh.," Malaysian Online J. Educ. Technol., vol. 3, no. 3, pp. 35-45, 2015.

[7] Sadirman, Interaksi dan Motivasi Belajar Mengajar. PT Grafindo Persada, 2011.

[8] N. S. Sukmadinata, Metode penelitian pendidikan. Program Pascasarjana Universitas Pendidikan Indonesia dengan PT Remaja Rosdakarya, 2005.

[9] S. Arikunto, Prosedur penelitian: Suatu pendekatan praktik. Rineka Cipta, 1992.

[10] Sugiyono, “Statistika Untuk Penelitian,” Bandung: Alfabeta, 2013.

[11] T. Winarsunu, Statistik dalam penelitian psikologi dan pendidikan. Penerbitan Universitas Muhammadiyah Malang, 2002. 
